\title{
ARCHETYPY I SYMBOLE W BAŚNIACH EUROPEJSKICH I ARABSKICH JAKO MODELE REKONSTRUKCJI KULTUROWEGO OBRAZU ŚWIATA. STUDIUM PORÓWNAWCZE
}

\author{
Archetypes and Symbols in European and Arabian Fairy Tales as Models \\ of Reconstruction of the Cultural Image of the World. Comparative Study
}

Keywords: archetypes, symbols, Eauropean fairy tales, Arabian fairy tales, culture, literature, cultural imagine of the world

Contact: Akademia Ignatianum w Krakowie; kontakt@dorotabeltkiewicz.pl

\section{„Baśnie sa perła w koronie dziedzictwa kulturowego.” \\ Maria Molicka}

\section{Baśnie w kulturze}

Nazwa gatunku baśń wymaga wnikliwej analizy strukturalnej i etymologicznej, gdyż w niej zawiera się pochodzenie, przeznaczenie i przesłanie powstających w obrębie tego gatunku utworów. Ten odczasownikowy rzeczownik wskazuje na związek z działaniem, najważniejszym narzędziem i elementem kultury - mową. Zbigniew Baran zwraca uwagę na pierwiastek ba- (mówić), który obejmuje szerokie pole semantyczne, a w jego centrum można z pewnością umieścić prasłowiańskie bajati i bajiti o pierwotnym znaczeniu: mówić, opowiadać oraz sufiks -śń tworzący rzeczowniki odczasownikowe (Baran 2006: 14). Odwołuje się także do pokrewieństwa pierwiastka $b a$ - do praindoeuropejskiego rdzenia bhA- znaczącego: powiadać (Bańkowski 2000: 35). Pradawny rodowód baśni potwierdza fakt, iż przekazywane były one ustnie (tworzone w czasach przedpiśmiennych). Ich wartość kulturową definiuje zatem ciągła żywotność w czasach, gdy ludy dawne nie znały innego sposobu utrwalenia i przekazu opowieści. Zbigniew Baran stwierdza: „w nazwie gatunku literackiego (baśń) jest zakodowana informacja o jego genezie: baśń to tekst o-powiadany" (Baran 2006: 14). 
Archetypy i symbole w baśniach europejskich i arabskich jako modele rekonstrukcji kulturowego obrazu świata. Studium porównawcze

W późniejszej leksykografii pojawia się zbieżność tego terminu z bajka. Różnice gatunkowe między baśnią i bajką są wyraźne, co wymaga systematyzacji. Oba gatunki mają charakter fabularny, jednakże odmienna jest ich struktura i funkcja, co wykrystalizowało się na drodze ewolucji obydwu gatunków. Choć Przewodnik Encyklopedyczny. Literatura Polska z 1984 roku odsyła jeszcze poszukującego terminu baśń do hasła bajka, a potocznie baśń i bajka uważane są - nie tylko w języku polskim - za synonimy, to współcześni badacze wyraźnie różnicują te gatunki, co więcej, tworzone są coraz to nowe typologie dla każdego z tych gatunków.

Bajka to krótki utwór fabularny bazujący na przedstawieniu parabolicznym, z użyciem motywów dobrze utrwalonych w świadomości społecznej oraz tradycji literackiej (Woźnowski 1984: 40). Forma i treść bajki jest zatem łatwa w odbiorze, a przesłanie klarowne dla adresata, często dodatkowo wzmocnione jako puenta wypowiedziana wprost niekiedy już na wstępie bajki albo mocno zasugerowana czytelnikowi (Jaworski 1985: 355). Bajka służyła na ogół dydaktyzmowi, pouczenie wyrażone było wprost.

Baśń natomiast stanowi utwór dłuższy, często wielowątkowy, który nie zawiera gotowego modelu myślenia i postępowania, a pomaga odbiorcy we własnych poszukiwaniach piękna, dobra i prawdy. Zbigniew Baran pisze: „zaznajamia ona czytelnika $\mathrm{z}$ dwoma aspektami sytuacji egzystencjalnej człowieka: aspektem istnienia cielesnego, podkreślającym to, iż człowiek jest częścią przyrody oraz aspektem egzystencji duchowej, wyrażającym to, że człowiek jest istotą duchową. Pomaga odkryć pewne aksjomaty: o wartości człowieka i świata, o sensie życia i śmierci, o sensie bycia kobietą, mężczyzną lub dzieckiem, czy też wreszcie o tożsamości człowieka z kosmosem. Ukazuje wydarzenia egzystencjalne, istotne w życiu każdego człowieka (...)” (Baran 2006: 6-7). Baśń skłania do osobistej refleksji, nie daje gotowego schematu interpretacyjnego, nie wyraża pouczenia wprost. Maria Molicka zauważa, że „Baśnie stymulują rozwój rozumowania moralnego, jednak same nie są tak do końca opowieściami moralnymi. Zdarza się, że protagonista, by obronić się przed przemocą, zachowuje się podstępnie, ujawniając mniej szlachetne zachowanie. Zawsze jednak baśnie niosą ze sobą ważne informacje, że należy być dobrym, sprawiedliwym, dotrzymywać zobowiązań bez względu na konsekwencje, a wówczas otrzyma się oczekiwaną nagrodę" (Molicka 2011: 204).

\section{Kulturowy obraz świata}

Baśni nie należy interpretować w oderwaniu od kultury, w której powstała. Znajomość realiów obyczajowych i tradycji, w której opowieść ma swoje korzenie, pozwala 
właściwie odczytać i zrozumieć nie tylko fabułę, lecz także przesłanie. „Baśnie stanowią kulturowe dziedzictwo, bo były i są odbiciem czasów i problemów społeczeństw, w których powstają. Posiadają znaczenie zależne od kulturowego kontekstu, w którym były formowane, ponieważ są tworem kultury" (Molicka 2011: 190).

Baśnie zawierają w sobie kulturowy obraz świata danej społeczności. Pozwalają także na rekonstrukcję tegoż w oparciu o charakterystykę postaci, opis warunków życia, przebiegu przygód. Analiza opowieści powinna bazować na konstruktywistycznej koncepcji kultury, wedle której „Kultura jest rzeczywistością znaków, jest ona zjawiskiem semiotycznym o charakterze systemowym. (...) Wszędzie tam, gdzie występują znaki, a więc i znaczenia, i generowane są dyskursy, mamy do czynienia z systemem kultury. Kultura nie jest więc czymś dającym się ustalić lub określić w sposób statyczny, lecz jest wiązką mechanizmów i zasad funkcjonujących tam, gdzie generowane są znaki” (Anusiewicz, Dąbrowska, Fleischer 2000: 13-14).

Wszelkie przemiany społeczno-kulturowe w obrębie kultur narodów czy kontynentów należy uwzględnić przy analizie baśni. Jak zaznaczyła cytowana Maria Molicka baśnie uczą dobrego postępowania, zmierzają ku prawdzie, dobru i pięknu, w historii jednak przybierały formę ,represyjnie moralizatorską”, zwłaszcza w XIX wieku. Wielu uważało je za niezmiennie (Bruno Bettelheim, bracia Grimm, Walt Disney), autorka ta zaznacza jednak ich liczne transformacje, w zależności od specyfiki audytorium, do których były adresowane, jak i celów, którym służyły (Molicka 2011: 190).

Odbiorca baśni i badacz powinien mieć świadomość funkcjonowania w kulturze wielości wersji tej samej opowieści baśniowej, której - na ogół - zakończenie jest tożsame, niemniej konstrukcja fabuły uległa znacznemu zniekształceniu (przykładem moją być baśnie braci Grimm czy Andersena - i ich odbiegające od pierwowzorów obecne wersje przedstawiane dzieciom).

\section{Religia w kulturze}

Baśnie, zarówno europejskie, jak i arabskie, chociaż oparte na dawnych wierzeniach ludowych, kształtowane były przez wieki, gdy już na Starym Kontynencie zakorzeniało się chrześcijaństwo, a w krajach arabskich - islam. Aspekt religijny, jako element kulturowego obrazu świata rekonstruowanego na podstawie baśni, jest bardzo interesujący i warto poświęcić mu odrębne opracowanie. Znamiennym jest jednak, że w baśniach europejskich słowo Bóg w dialogach pojawia się bardzo rzadko, najczęściej w emocjonalnych wykrzyknieniach wyrażających przestrach, lęk lub politowanie 
Archetypy i symbole w baśniach europejskich i arabskich jako modele rekonstrukcji kulturowego obrazu świata. Studium porównawcze

(przykładowo: „O, Boże!”, „Na Boga!”, „Pożal się Boże!”), jako sam istota boska sporadycznie. W baśniach arabskich pojawia się jako byt absolutny - stwórca, prawodawca, sędzia. W dialogach bohaterowie odwołują się do niego, przykładowo: „Ja jestem tylko słabym człowiekiem, ale Bóg wynagrodził moją słabość i ubóstwo wiedzą.” z baśni „Dżuha i trzech astrologów” (Dziekan 2015: 15); „Nie ożenię się z moją siostrą ani nie będę domagał się spadku, aby niczego nie być winnym przed Bogiem, ani przed sługami Boga” z baśni „, Trzech Hasanów” (Dziekan 2015: 24).

Warto zauważyć, że - analogicznie - zło w baśniach europejskich rzadko jest prezentowane bezpośrednio poprzez diabła czy demona (poza nielicznymi cyragroficznymi wątkami, najczęściej pojawia się również w wykrzyknieniach: „Do licha!"). W baśniach arabskich szatan jest prezentowany wprost (przykładowo: w baśniach „Muł w czajniku”, „O łańcuchowym diable”) jako kusiciel, zwodziciel, pogromca pyszałków.

\section{Archetypy i symbole}

Baśnie są skarbnicą znaków, wiele elementów pojawia się w nich nieprzypadkowo. Maria Molicka odwołuje się do Junga nazywając baśń „reprezentacją nieświadomości zbiorowej”, dodając: „Archetypy to idee pierwotne, tak jak materia utkana jest z elementarnych cząstek, tak idee pierwotne - archetypy - tworzą zaczątek życia psychicznego“ (Molicka 2011: 188). Zbigniew Baran stwierdza: „Wnikliwa lektura baśni pozwala dostrzec ich mityczny aspekt i ich archetypową strukturę (...) Baśń literacka z natury rzeczy bywa symboliczna lub alegoryczna, a ogóle aksjomaty są wdrażane w tekście konkretnymi symbolami” (Baran 2006: 9). Symbol zaś autor ujmuje tak: „(...) symbol jest odzwierciedleniem esencji idei lub esencji emocji przez znak” (Baran 2006: 158), kryje się w nim tajemnica. Baśnie, prezentując moralne postawy i życiowe wybory, nie są więc wolne od emocji. Fabuła jest tym bardziej interesująca, jeśli bohater przeżywa głęboko emocje, targają nim dylematy, musi podjąć ryzyko. „Powtarzanie baśni i wielokrotne wracanie do nich oswaja z sytuacją zagrożenia, przygotowuje do różnych trudności, daje poczucie bezpieczeństwa poprzez iluzję kontroli, co sprzyja redukcji napięcia" (Molicka 2011: 208). Baśnie uczą także empatii, współodczuwania, bohaterowie opowieści zaszczepiają wrażliwość na drugiego człowieka. 


\section{Badania nad baśniami}

Baśń jest dla badaczy nośnikiem wiarygodnych informacji o kulturze, w której powstała, utrwaliła się i jest kultywowana. Opowieści analizowane i opracowywane są na ogół wedle wąskich kategorii: autora, regionu, kraju (szerzej: kontynentu). Stosunkowo rzadkie i fragmentaryczne są prace dotyczące baśni europejskich i arabskich, stanowiące studium porównawcze. Ta pierwsza grupa tekstów jest dość szeroko opisana, przeanalizowana przez rodzimych badaczy europejskich. Popularne są prace zestawiające i porównujące europejskie baśnie narodowe, a także transformacje tekstów popularnych autorów (Andersen, bracia Grimm) na przestrzeni wieków. Dostrzegalny jednak deficyt opracowań komparatywnych międzykontynentalnych i międzycywilizacyjnych.

Odrębnym, bardzo szerokim, jednakże wartym zasygnalizowania tematem jest interkontynentalna i - można powiedzieć - intercywilizacyjna migracja baśni oraz zjawisko akulturacji. Baśnie arabskie wszak przyjęły się na Starym Kontynencie i funkcjonują w edukacji i wychowaniu, lecz także w rozrywce, sztuce - szeroko pojętej kulturze, baśnie europejskie natomiast znane są w krajach arabskich, choć w mniejszym stopniu. Warto zwrócić uwagę, że produkcje filmowe zarówno baśni europejskich, jak i arabskich prezentowane globalnie prezentują dość sugestywny, odrealniony świat, oczyszczone są z wszystkiego, co nieprzyjemne, spłycona została fabuła na rzecz banalnego schematu.

\section{Przykłady symboli i archetypów}

Archetypy i symbole zawarte w baśniach europejskich i arabskich bywają tożsame, niemniej ich obrazowanie wskazuje na znaczące różnice kulturowe. Pierwszym etapem studiów porównawczego jest selekcja baśni europejskich i arabskich wedle kryterium tożsamości archetypów oraz ich analiza i opis obrazowania tamże.

- Symbolika liczb

Wnikliwe analizy tekstów baśniowych wykazują na dominację liczb nieparzystych, zwłaszcza - 3 i 7, które dla wielu kultur są kluczowymi i uznawanymi za magiczne.

Liczba 7 w wielu kulturach uznawana jest za symbol doskonałości, lecz także nieskończoności, mnogości, bogactwa. Odwołać się warto do aktu stworzenia świata w którym dzień siódmy (wedle różnych wyznań) uważany jest za dzień dokończenia dzieła stworzenia i zwieńczenia przez Boga odpoczynkiem. W językach słowiańskich zwłaszcza polskim - wyrażenie „siódme niebo“ oznacza najwyższy stopień szczęśliwości. Jak zaznacza Jerzy Bralczyk: „Być w siódmym niebie, czyli: czuć się 
Archetypy i symbole w baśniach europejskich i arabskich jako modele rekonstrukcji kulturowego obrazu świata. Studium porównawcze

szczęśliwym, czuć się błogo. Według żydowskiej, ale także i muzułmańskiej kosmografii nieb jest właśnie siedem, a ostatnie jest siedzibą Jehowy (ewentualnie Allacha). Być tam nie można, ale można, przeżywając najwyższe stany błogości lub euforii, czuć, że większego szczęścia nie sposób doznać. Ciekawe, że nie tylko sobie samym, lecz także innym przypisujemy takie uczucia, sądząc, rzecz jasna, po pozorach.”

Wielokrotność 7 - 77 uważana była za liczbę nieskończoności, wieczności. Często pojawiający się w baśniach europejskich wstęp: „Za siedmioma górami, za siedmioma lasami (...)" wprowadzają odbiorcę w klimat tajemniczości, miejsce i czas są odległe, rozległe, nieokreślone, tajemnicze. Celem podkreślenia obfitości, bogactwa i różnorodności liczba 7 określa zbiorowość bohaterów - siedmiu krasnoludków towarzszących Królewnie Śnieżce, czy siedem koźlątek w baśni „O wilku i siedmiu koźlątkach". W baśniach arabskich liczba ta - mimo iż istotna i funkcjonująca w sferze religijnej i społecznej - występuje rzadko.

Tożsama dla obydwu baśni Europejczyków i Arabów jest liczba 3. Najczęściej ukazuje ona triadę różnych cech, ułożoną w sposób gradacyjny prezentowanych przez różnych bohaterów: pośród opowieści europejskich: „Złotowłosa i trzy niedźwiadki” (trzy odmienne postaci, stwarzające dla Złotowłosej okazję wyboru akcesoriów rodziny podczas nieobecności) „Trzy małe świnki” (trzy różne postawy wobec obowiązku zbudowania domu), pośród arabskich” „Dżuha i trzech astrologów” (gradacyjne pytania trzech mędrców kierowane do głównego bohatera, którego bystre odpowiedzi okryły ich wstydem i hańbą), „Trzech Hasanów” (których spostrzeżenia również układają się gradacyjnie).

W baśniach arabskich i europejskich często podejmowane są trzykrotne próby („Rybak i dżin” - trzykrotne zarzucanie sieci, „Złota rybka” - trzykrotne spełnianie życzenia, „Królewna Śnieżka” macocha trzykrotnie usiłuje zabić Śnieżkę).

- Archetyp łowcy

Popularnym archetypem baśniowym jest poszukiwacz, poławiacz, łowca. Popularna europejska baśń „O rybaku i złotej rybce” (spisana przez braci Grimm) ma bliźniaczą we wstępie - opowieść wschodnią „Rybak i dżin”. Historia zaczyna się bardzo podobnie: biedny rybak rozpoczyna pracę w oczekiwaniu na pomyślny połów, pośród morskich wód dostrzega niezwykły obiekt. Europejska baśń prezentuje rybaka, który w sieci znalazł złotą rybkę - uwolnił ją, za co zostaje nagrodzony - trzykrotnie przekazuje magicznemu zwierzęciu życzenie dyktowane przez żonę świadczące o jej pysze i braku pokory (nowa balia, nowy dom, pałac i klejnoty). W efekcie złota rybka 
pozbawia rybaka i jego żonę wszystkiego, co podarowała, a małżeństwo wraca do realiów sprzed spotkania niezwykłej ryby - smutne i zawiedzione.

W baśni wschodniej natomiast rybak za trzecim razem łowi niezwykłe naczynie, ma nadzieję, iż napełnione jest bogactwem, okazuje się jednak, że przechowuje ono złego dżina, który w odwecie za uwięzienie przez króla zaprzysiągł zamknąć w naczyniu tego, kto go uwolni. Rybak, mimo przestrachu i trwogi o własną wolność, zachowuje opanowanie i podstępem nakazuje dżinowi wrócić do naczynia pod pretekstem sprawdzenia, czy w wazie zmieści. Następnie ponownie więzi dżina i nie daje się przekonać obietnicom, że ten zapewni mu bogactwo, władzę i spełni każdą zachciankę. Rybak szczęśliwy wraca do swojej rodziny, jako zysk i nagrodę traktuje ocalenie własnej wolności.

Nagroda i zysk są częstym celem działań bohatera baśniowego. Dydaktyzm pokazuje, iż należy cieszyć się z drobnych, stopniowych postępów, które nie zostały docenione przez żonę rybaka, kierującej jego wyborami, co doprowadziło do utraty wszystkich nowych dóbr. Baśń wschodnia pokazuje nagrodę rozumianą jako brak utraty posiadanego już dobrostanu (zasobów majątkowych lub niematerialnych) w przypadku rybaka: zachowanie wolności i możliwość powrotu do rodziny.

- Archetyp macochy

Macocha, druga żona ojca, pojawia się często w baśniach europejskich i arabskich. Postawa tej kobiety jest negatywna, a jej oddziaływanie na pasierbicę (gdyż przybranym dzieckiem jest najczęściej dziewczyna) pełne uprzedzeń i nierzadko agresji.

W „Kopciuszku” (pierwsze opracowanie Perraulta) pasierbica jest nieszczęśliwa, poniżana, samotna, obciążona pracą i brakiem komfortu, odsunięta od możliwości pójścia na bal. Rodzone córki macochy są faworyzowane, co pogłębia cierpienie dziewczyny. Z opresji wybawia ją wróżka, która umożliwia udział w przyjęciu, a potem sprzyja jej upór księcia poszukującego jej z zagubionym pantofelkiem.

Drastyczniejszą postawę prezentuje macocha w baśni „Królewna Śnieżka” (spisanej przez braci Grimm), która zleca zabójstwo pasierbicy. Gdy dowiaduje się, że zostało ono zaniechane, usiłuje ją zabić - gorsetem, zatrutym grzebieniem, w końcu wykorzystując naiwność dziewczyny - częstuje ją zatrutym jabłkiem, które pozbawia ją życia. Szczęśliwym trafem przejeżdżający obok książę zakochuje się w niej i magicznym pocałunkiem przywraca ją do życia.

Baśń arabska „O czarnych psach” łączy w sobie wątki tych dwóch baśni europejskich. Zła macocha posiada własną córkę, którą faworyzuje kosztem pasierbicy, utrudnia jej codzienne czynności, naprzykrza się. Sprawia, że pies zostaje z panną 
Archetypy i symbole w baśniach europejskich i arabskich jako modele rekonstrukcji kulturowego obrazu świata. Studium porównawcze

„zaślubiony” i zamknięty $\mathrm{w}$ jednym pokoju, ta życzy pasierbicy śmierci przez pokąsanie. Wielkie jest jej zdziwienie, kiedy pies (pod którego postacią ukryty był dżinn) zamienia się w mężczyznę i zapewnia dziewczynie dostatnie i szczęśliwe życie. Wydaje wtedy macocha swoją córkę za przypadkowego psa w nadziei na tożsamy pomyślny los dla niej, zamyka zwierzę na noc z dziewczyną. Nad ranem znajduje szczątki córki i ogryzione kości. Los każe macochę za jej okrucieństwo, wymierzając najgorsze cierpienie - śmierć własnego dziecka. Złorzeczenie pasierbicy wraca do niej w postaci bolesnej, nieodwracalnej straty.

Zarówno Kopciuszek, jak i Śnieżka, dzięki ingerencji zakochanego księcia są w końcu szczęśliwe, podobnie jak ich arabska odpowiedniczka. Baśnie różnią się jednak zakończeniem. Rozmaite wersje baśni ukazują różne kary dla macoch europejskich niemniej najczęściej jest to samosąd lub zemsta otoczenia głównej bohaterki, nie zaś bezpośrednia i natychmiastowa kara od losu.

Przytoczone przykłady ukazują różnice światopoglądowe w kulturach - europejskiej i arabskiej.

\section{Podsumowanie}

Baśnie stanowią nie tylko źródło rozrywki i wiedzy dla odbiorców, lecz są także znakomitym materiałem do analizy przez badaczy, umożliwiającym rekonstrukcję kulturowego obrazu świata społeczności, w której powstały i funkcjonują. Opowieści te odzwierciedlają hierarchię wartości typową dla danej społeczności, ukazują relacje między jej członkami, modele postępowania, pojmowanie dobra i zła, stopień zakorzenienia religijnego. Zbigniew Baran nazwał baśn „literackim obrazem człowieka i jego sytuacji egzystencjalnej” (Baran 2006: 6). Żywotność baśni - jeśli opowieść przekazywana jest stale pokoleniowo - świadczy o jej uniwersalności i ponadczasowości, mimo licznych transformacji na przestrzeni wieków. Niniejsze opracowanie stanowi wyłącznie wstęp do szerszych badań porównawczych nad baśniami europejskimi i arabskimi, które dotychczas zestawiane były stosunkowo rzadko. Zaprezentowany materiał jest jedynie wąskim wycinkiem ogromnego dziedzictwa Europejczyków i Arabów, niemniej już na wstępnym etapie analizy sygnalizuje kwestie odmienne i tożsame.

Baśnie europejskie i arabskie różni budowanie klimatu opowieści poprzez zastosowanie symboliki liczb: baśnie Starego Kontynentu silnie na niej bazują, podczas 
gdy w baśniach arabskich dominuje stosowanie triady (bohaterów, gestów, czynów) jako gradacji cech i postaw.

Ważna jest także nagroda przyświecająca postępowaniu bohatera - w baśniach europejskich i arabskich często przybiera ona postać materialną, fizyczną: ożenek czy bogactwo, niemniej w baśniach Arabów pojawia się także inny aspekt nagrody rozumiany jako brak utraty posiadanego już dobrostanu (zasobów majątkowych lub niematerialnych).

Baśnie arabskie wykazują silniejsze zakorzenienie religijne - Bóg i szatan jest obecny w życiu bohaterów, co czyni ludzkie życie bardziej uduchowionym, w baśniach europejskich walka dobra ze złem jest oczywista, niemniej ujęta jest w konstrukt kontrastu postaci ludzkich lub zwierzęcych.

Pojawiająca się w opowieściach baśniowych magia jest wszechobecna, w mniejszym stopniu warunkuje jednak losy bohaterów arabskich (dominuje mądrość, spryt, siły witalne, wiara) niż europejskich (o przygodach postaci decyduje przypadek, pomyślne zrządzenie losu, cudowny przedmiot czy istota).

$\mathrm{W}$ odniesieniu do relacji rodzinnych prezentowanych $\mathrm{w}$ baśniach odnosi się wrażenie, że - wybrany $\mathrm{z}$ wielu - archetyp macochy w podobny sposób funkcjonuje wśród Europejczyków i Arabów, niemniej niewłaściwe zachowanie wobec pasierbicy/pasierba jest dotkliwiej karane przez los w baśniach arabskich, co przestrzega przed brakiem litości wobec wychowanka.

Pomimo różnych symboli zawartych w baśniach, wpływających na ich percepcję, pomimo różnych konstrukcji fabularnych oraz słabszego lub silniejszego zakorzeniania religijnego, najważniejsza jest triada: dobro, prawda, piękno. Opowieści te ukazują dążenie ludzi dobrostanu, czy to w perspektywie doczesnej, czy wiecznej. Marek M. Dziekan, we wstępie do zbioru opowieści arabskich, stwierdził: „Człowiek wszędzie jest człowiekiem. I choć zawsze kształtuje go kultura, to niektóre problemy mają charakter ogólnoludzki” (Dziekan 2015: 9). Taką uniwersalną, ogólnoludzką, ponadkulturową i ponadkontynentalną potrzebą, przyświecającą ludzkiej egzystencji jest szczęście, co ukazują baśnie europejskie i arabskie.

\section{Summary}

Fairy tales are not only a source of entertainment and knowledge for recipients, but are also an excellent material for analysis by researchers. These stories reflect the hierarchy of values, the models of behaviour, the understanding of good and evil. This study is only an introduction to a broader comparative study of European and Arabian fairy tales. 
Archetypy i symbole w baśniach europejskich i arabskich jako modele rekonstrukcji kulturowego obrazu świata. Studium porównawcze

Despite the various symbols contained in the fairy tales, affecting their perception, despite the different feature constructions and the weaker or stronger religious rooting, the most prominent is the triad: good, truth, beauty. Supracultural and supracontinental need, guiding human existence, is happiness, which is shown by European and Arabic fairy tales.

\section{Literatura}

Anusiewicz, J., Dąbrowska, A., Fleischer, M. Językowy obraz świata i kultura. Projekt koncepcji badawczej. Acta Universitatis Wratislaviensis Język a Kultura. 2000 (13/2218), s. 11-44.

Bańkowski, A. Etymologiczny słownik języka polskiego. Tom 1: A-K. Warszawa: Wydawnictwo Naukowe PWN, 2000.

Baran, Z. Idee - mity - symbole w polskich baśniach literackich wydanych w XIX i XX wieku. Kraków: Wydawnictwo Naukowe Akademii Pedagogicznej, 2006.

Borecka, I. Z motylem $w$ tle. $O$ baśni $w$ biblioterapii i terapii pedagogicznej. Wałbrzych: Wydawnictwo Państwowej Wyższej Szkoły Zawodowej w Wałbrzychu, 2004.

Dziekan, M. M. 28 bajek arabskich. Warszawa: Wydawnictwo Blue Bird, 2015.

Jaworski, S. Bajka. In: Majda, J. (ed.) Okresy literackie. Warszawa: Wydawnictwa Szkolne i Pedagogiczne, 1985, s. 355.

Jung, C. G. Przetom cywilizacji. Warszawa: Wydawnictwo KR, 2009.

Jung, C. G. Psychologia a religia Zachodu i Wschodu. Warszawa: Wydawnictwo KR, 2005.

Jung, C. G. Życie symboliczne. Warszawa: Wydawnictwo KR, 2007.

Krynicka, I. (ed.) Złota księga bajek. Opowieści ze wszystkich stron świata. Warszawa: Grupa Wydawnicza Foksal, 2013.

Molicka, M. Biblioterapia i bajkoterapia. Rola literatury w procesie zmiany rozumienia świata społecznego i siebie. Poznań: Media Rodzina, 2011.

Woźnowski, W. Bajka. In: Krzyżanowski, J., Hernas, C. (eds.) Literatura Polska. Przewodnik encyklopedyczny. Warszawa: Państwowe Wydawnictwo Naukowe PWN, 1984, s. 40.

Dostęp z: https://sjp.pwn.pl/ciekawostki/haslo/Byc-w-siodmym-niebie;5391670.html (2020-05-05). 